\title{
Forecasting Analysis on Land Detection System Based on Geographic Information System
}

\author{
Warnia Nengsih ${ }^{1}$
}

\begin{abstract}
Geographic Information System (GIS) is an information system that performs geographic-based data visualization. The system performs mapping between various data points based on geographical location. Difficulties in mapping land in a region is the basis for the development of GIS applications for the detection of land. This system does not only detect vacant land in a region, but it also provides identification of land, and provides information about the size of the land, the land position, as well as access to nearby public facilities. The system is developed using a mobile platform as a value system that is more flexible and dynamic. For the analysis of the forecasting in an area uses a multiple regression method involving three independent variables, namely the use of dry land, the use of building land and land use. The results of the predictive forecasting provides location points of interest and public facilities located in the location which make it easy to give consideration in selecting a location which is appropriate to build.
\end{abstract}

Keywords-GIS, Android, land, forecasting, analysis, multiple regression.

\section{INTRODUCTION}

An area must have a good data collection system for vacant and ready-to-build lands. In addition to supporting government programs in terms of urban layout, it also helps long-term planning of the government, in this case the urban planning office. The absence of a complete mobile data system and flexible for data collection of land in a region is the reason for the development of this system. Difficulties in determining suitable locations to build in accordance with the criteria of the community by looking at the level of location density and even distribution of development become other considerations of the development.

Geographic Information System (GIS) for the detection of vacant land is developed using a mobile platform. This system is developed in order to provide solutions to existing problems. This system will perform good data collection for vacant and ready-to-build land in the form of mapping and provide vacant land information by identifying the land, size, land position, and access to nearby public facilities. An analysis of forecasting in a region is done using a multiple regression method as part of the regression technique to make it easier for the public to know the point of the most desirable location.

\section{Methodology}

This study is an Android-based GIS. According to Good Child, the GIS is a component consisting of hardware,

\footnotetext{
${ }^{1}$ First Author, Politeknik Caltex Riau, Jalan Umbansari No 1 Rumbai 28265 Pekanbaru Riau Indonesia (tlp:0761-53939; fax:0761-554224; e-mail: warnia@pcr.ac.id)
}

software, geographic data, and human resources that work together effectively to incorporate, store, fix, update, manage, manipulate, integrate, analyze and display data in a geographic-based information [1]. Conceptually, the GIS is part of Management Information System. Management Information System is a set of comprehensive and coordinated and rationally integrated information subsystem capable of transforming data so that it becomes information through a series of ways to improve productivity that match the style and nature of managers on the basis of predetermined quality criteria [2] The beneficent uses of GIS technology must be weighed against its nefarious uses. However, the laws governing the protection, management and use of spatial data remain are undeveloped, uncertain and unclear. These legal uncertainties impose additional burdens and place constraints on the wider adoption and use of the technology [3].

Pekanbaru has 12 subdistricts and 58 urban villages that serve as location points. There are data on the use of dry land, the use of building soil, and the land used to find the data of vacant land worth waking up. The data used in the form of primary data.

Land is defined as a physical environment that includes climate, soil relief, hydrology, and plants that to some extent affect the ability of land use [4]. Land use is defined as any form of human intervention to land in order to meet the need of life [5].

Ways to conduct an inventory of land resources consist of two parts. The first section discusses the inventory of land resources (soil survey) and the second section discusses the interpretation of the results of an inventory of land resources or better known as land evaluation, so that the concept of quality information is met [6]. Quality information will assist functional or management in management decision making [7]. Quality information has three criteria, which are accurate, relevant, and timely.

The system also implements a forecasting analysis to predict viable ready-to-build locations using multiple regression methods. There are three variables used. Regression technique is one of the data mining techniques that belongs to predictive modeling. This technique is usually used to determine the pattern or trend that occurs, and usually also used for a forecasting analysis. This technique conceptually uses learning data obtained from existing data. There are several types of regression techniques, including linear regression and multiple regression.

Multiple regression is used to measure the effect of more than one predictor variable on the dependent variable, or the effect of $x$ on $y$. In linear regression, $x$ is used only one variable. However, in multiple regression, $x$ and $y$ are used for 
more than one variable. Equation (1) is used to obtain the regression equation.

$$
y=a+b_{1} x_{1}+b_{2} x_{2}+\ldots+b_{n} x_{n}
$$

with

$$
\begin{array}{ll}
y & : \text { dependent variable } \\
a & : \text { constant } \\
b_{1}, b_{2} & : \text { gradient } \\
x_{1}, x_{2}, x_{3} & : \text { independent variables }
\end{array}
$$

Equation formulas are formed using a matrix according to the number of free variables used.

A similar study conducted is a spatial analysis of management criteria as one of the criteria used to assess land criticality in protected forest areas [8]. Assessment is done based on the completeness of management aspects, including the existence of the boundary of the area, security and supervision, and the implementation or not extension.

\section{RESULTS AND DISCUSSION}

Generally, the architecture of this system can be described as in Fig. 1.

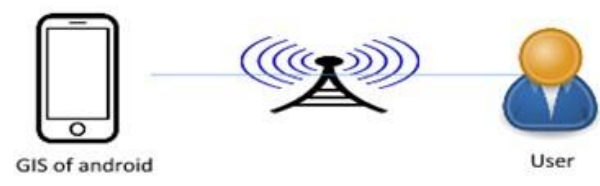

Fig. 1 General system architecture.

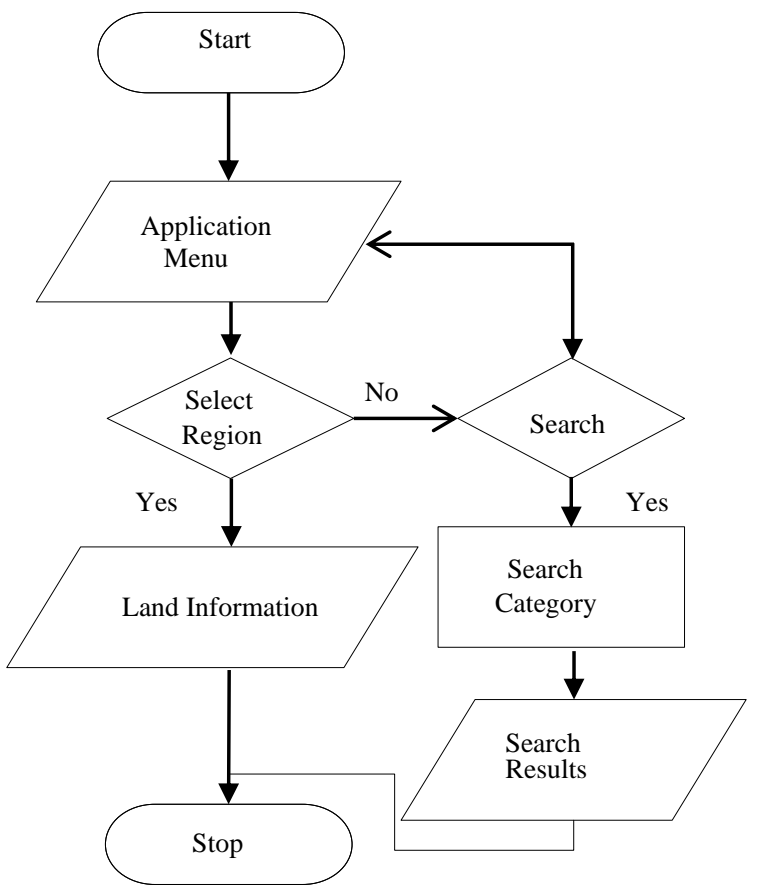

Fig. 2 System flowchart.

Fig. 1 describes system architecture in general. The GIS on Android contains land detection features using geographic mapping concepts. Users will access the system to obtain various land mapping information. Users in this case can be interpreted as general public and related offices associated with urban planning. System design is shown in Fig. 2.

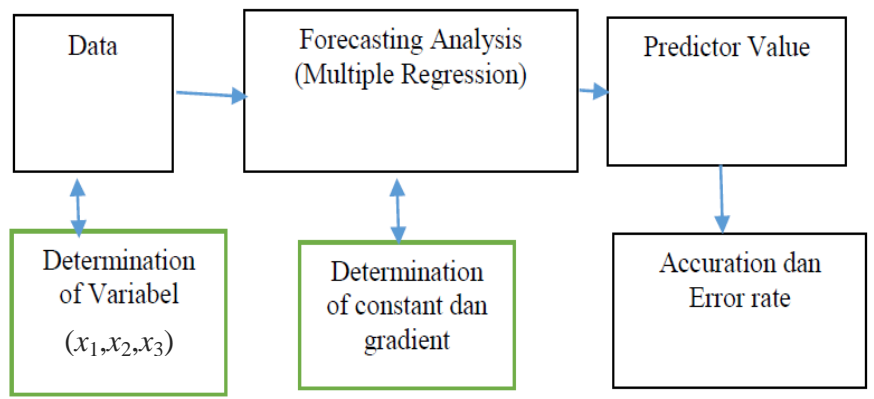

Fig. 3 Block diagram of the forecasting analysis.

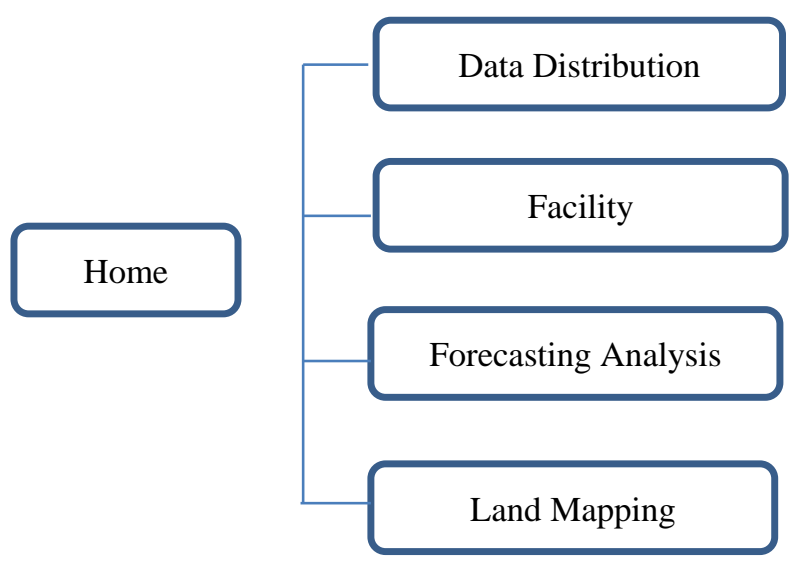

Fig. 4 GIS map.
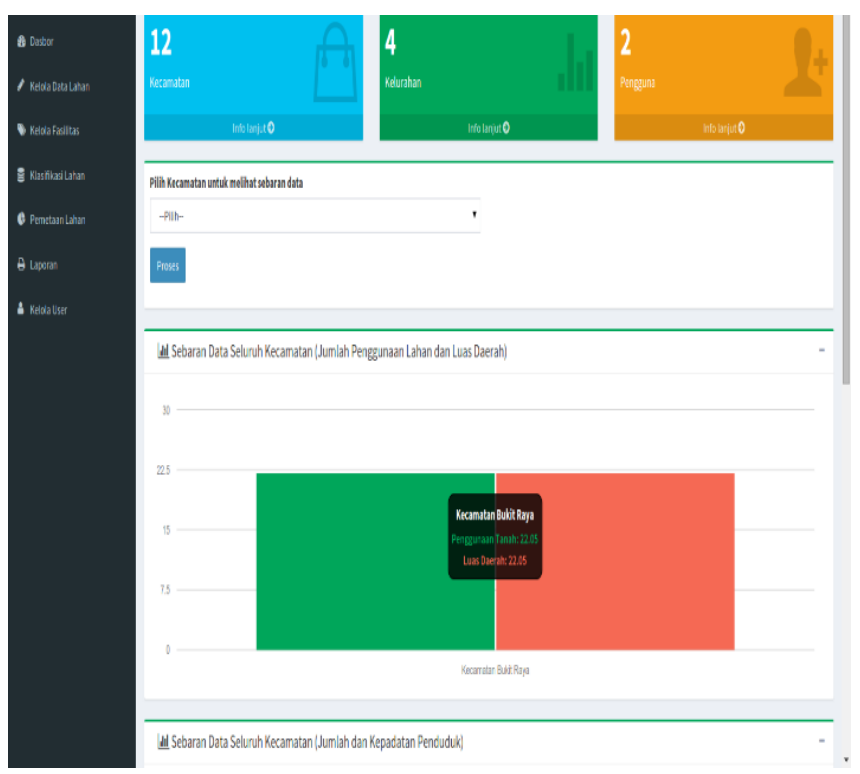

Fig. 5 Land maping using web platform.

Fig. 2 describes the system flow on the web platform. In general, public can view the data of ready-to-build lands as well as other necessary land information, and can search information based on certain categories. 


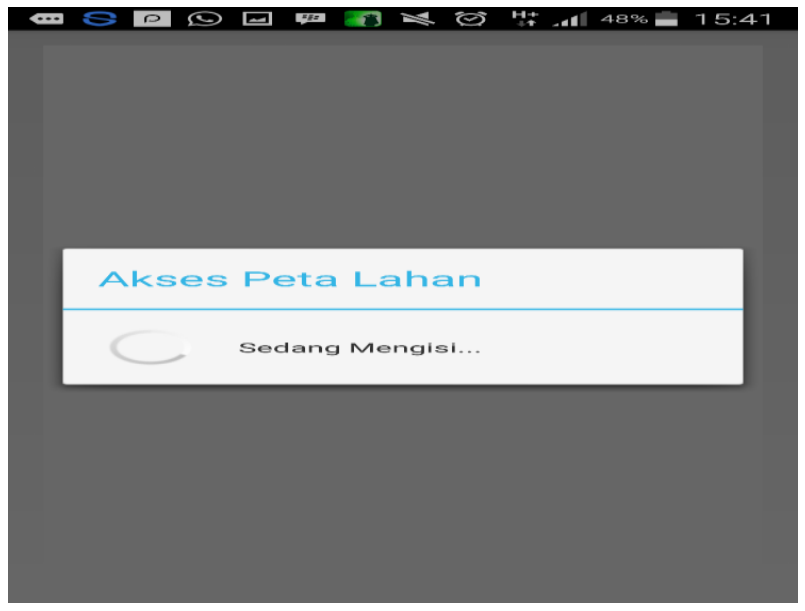

Fig. 6 Access map.

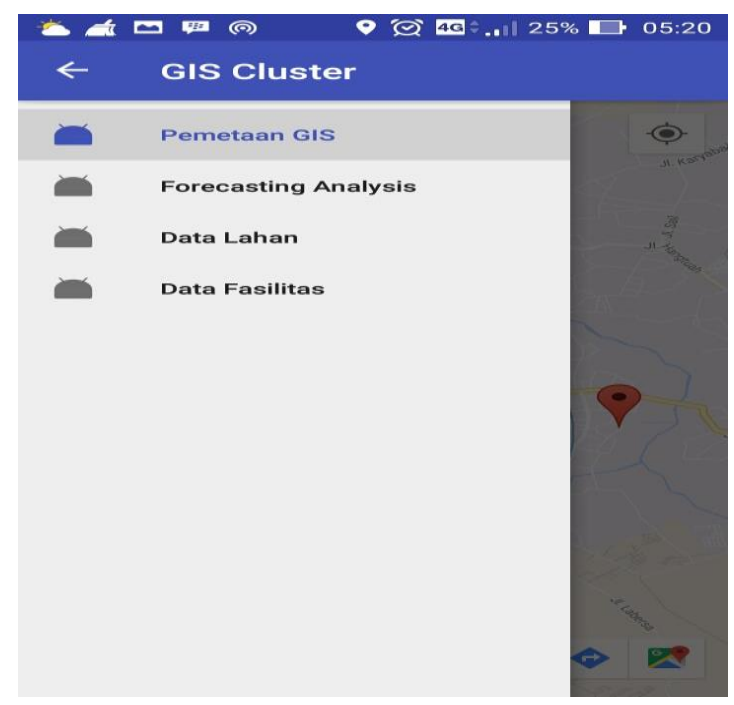

Fig. 7 GIS features on Android for land detection.

The forecasting analysis process is shown in Fig. 3. The data used are the land data in Pekanbaru. The data was processed using one method of forecasting called multiple regression. To find out the accuracy of predicted values generated, it was performed several series of tests.

The description of GIS Map features designed with the mobile platform is presented in Fig. 4. The figure describes the features of the land mapping system on Android. In general, it can be seen the features of data distribution, facilities, forecasting analysis, and land mapping.

Based on the design which has already been mentioned, this system produces two different platforms, namely web platform and Android platform. There is no significant difference between the two platforms, including the features in them. The existence of this platform aims to provide convenience for users without being limited by media used. Land mapping for web platforms is shown in Fig. 5, while the mapping system display for the Android platform, on access to land maps, is shown in Fig. 6.

Fig. 7 describes features found in the Android GIS for land detection systems, such as GIS readings, forecasting analysis, land data, and facility data. GIS mapping contains GIS features for each location point. Forecasting analysis is a feature point location pointing using forecasting analysis method. Land data contains information on land such as land area, amount of land used, and remaining usable land. On the other hand, the facility data contains facilities located around the point of location of the land.

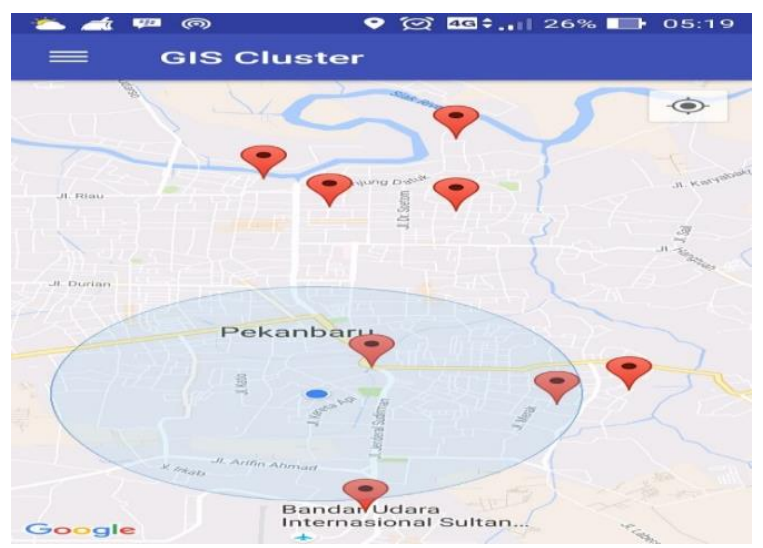

(a)

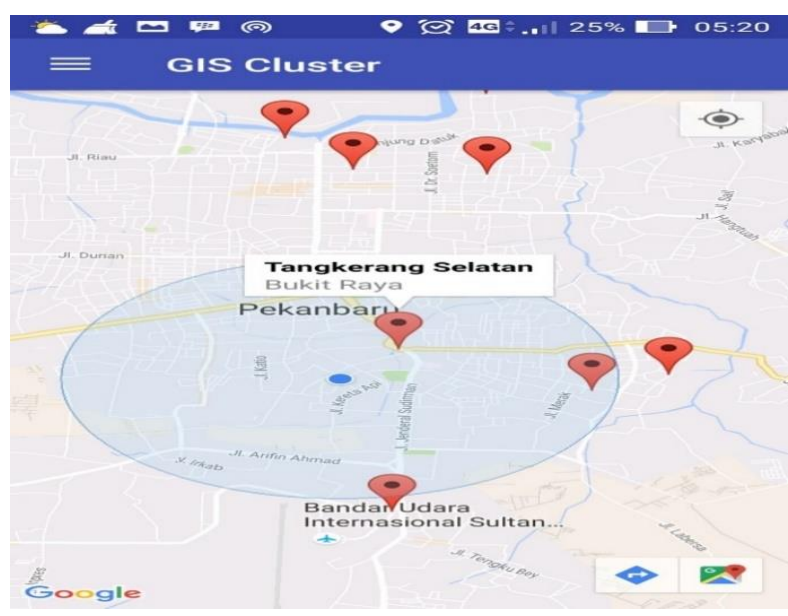

(b)
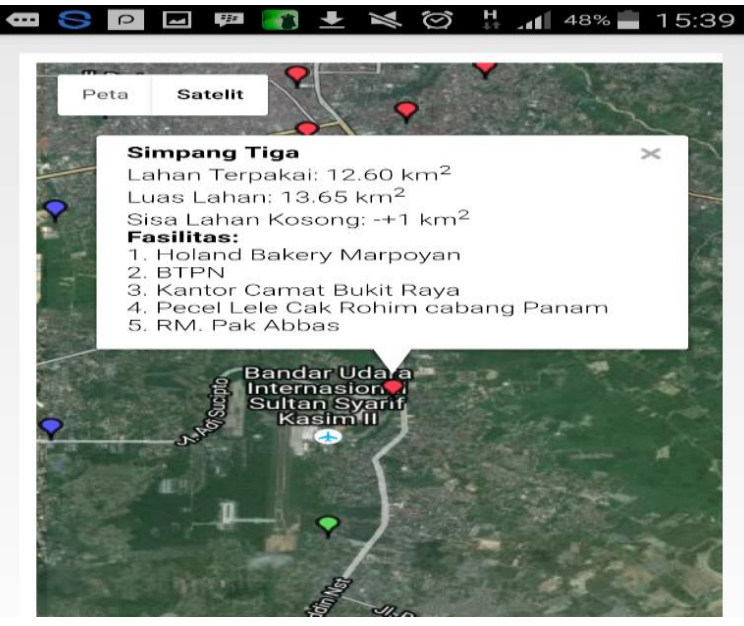

(c)

Fig. 8 Land mapping. 


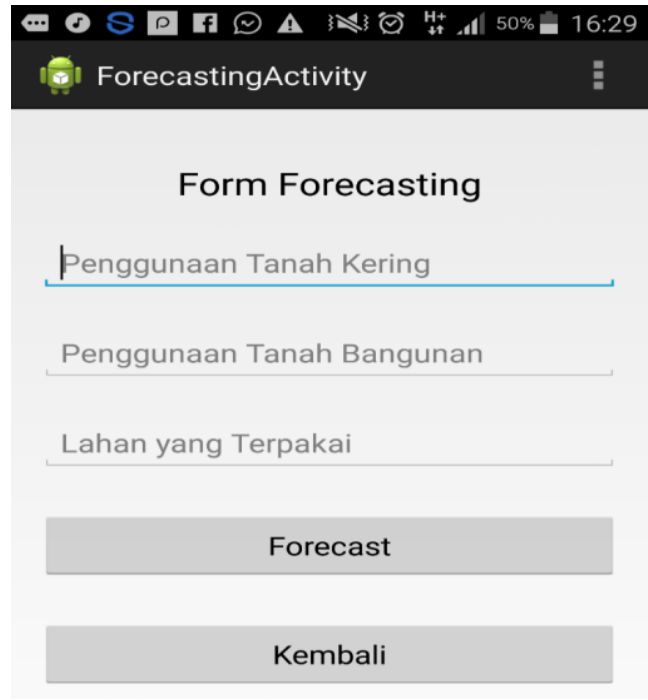

Fig. 9 Form forecasting display.

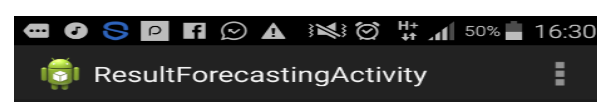

Hasil Forecasting
Tanah Kering: 1.0
Tanah Bangunan: 1.0
Lahan Terpakai: 100.0
Kecamatan: Data tidak ditemukan
Kelurahan: Data tidak ditemukan

Kembali

Fig. 10 Forecasting results with the data which are not found.

Fig. 8 shows land mapping used for each location point in each region. The selected location point contains a description of the land used, the area of land, and the remaining vacant land and the nearest facilities in a region. There are 56 location points spread over twelve sub-districts, with uneven distribution at each point.

On the other hand, there is a forecasting menu to facilitate the user in predicting possible locations that have an opportunity to access. There are three variables used, namely dry land use $\left(x_{1}\right)$, use of land for building $(x)$, and used land $\left(x_{3}\right)$. Forecasting is done using forecasting analysis multiple regression method with the resulting equation is

$$
y=29.5792+0.006459 * x_{1}+-0.00657 * x_{2}+0.00847 * x_{3}
$$

with the resulting gradient value is 29.5792 , the constant value 1 is 0.006459 , the constant value 2 is 0.00657 , and the constant value 3 is 0.00847 .

Fig. 9 shows the forecasting display on the Android platform. Then, Fig. 10 displays the forecasting result if the value in the variable used to estimate the point of a location is a value that falls outside the category. An error occurs as the data is not found.

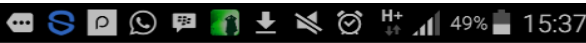 \\ ब्षि: ResultForecastingActivity}

\begin{tabular}{l} 
Hasil Forecasting \\
Tanah Kering: 1.0 \\
\hline
\end{tabular}

Tanah Bangunan: 1.0

Lahan Terpakai: 1.0

Kecamatan: Kecamatan Lima Puluh

Kelurahan: Tanjung Rhu

Kembali

Fig. 11 Correct forecasting results.

TABLE I

FORECASTING ANALYSIS TEST (RANDOM DATA)

\begin{tabular}{|l|l|l|l|}
\hline $\boldsymbol{x}_{\boldsymbol{1}}$ & \multicolumn{1}{|c|}{$\boldsymbol{x}_{\boldsymbol{2}}$} & \multicolumn{1}{|c|}{$\boldsymbol{x}_{\mathbf{3}}$} & \multicolumn{1}{c|}{$\boldsymbol{y}$} \\
\hline 1 & 1 & 1 & Tanjung Rhu \\
\hline 1 & 2 & 1 & S. Rumbai \\
\hline 1 & 2 & 3 & M. Limmbungan \\
\hline 2 & 1 & 3 & S.Lembah Damai \\
\hline 1 & 1 & 100 & Location not found \\
\hline 3 & 2 & 110 & Location not found \\
\hline
\end{tabular}

Furthermore, the results of the correct forecasting is shown in Fig. 11.

To perform the test that the method had been running well or not, it was used the method of fuctional testing. The range of values contained in $x_{1}, x_{2}$, and $x_{3}$ were tested, correct and incorrect, by testing the values into the system. Thus, the test results are appropriate, as presented in Table I.

With randomly-selected test data, it is found that if the value of the variable is not on the scope, the location data is not found.

\section{CONCLUSION}

The designed land mapping system besides detecting vacant land in areas, it also identifies land and provides information on land size, land positions, and access to nearby public facilities. The system is developed using a mobile platform, giving it more strenghts because it is flexible and dynamic. In addition, the system also provides information on prediction of the point of interest and public facilities in the location which makes it easier to give consideration of choosing a suitable location to build.

\section{REFERENCES}

[1] Cowen, D, 'What is GIS?' in NCGIA Core Curriculum, Goodchild \& Kemp (eds.), Santa Barbara, CA: NCGIA,1990.

[2] McLeod, Raymond \& Schell, George, Management Information Systems $10^{\text {th }}$ Edition. Prentice Hall, 2006. 
[3] Cho, G. "A Self-Teaching Student's Manual for Geographic Information Systems". Canberra: University of Canberra and CAUT,1995.

[4] Purwowidodo, Teknologi Mulsa, Jakarta, Dewaruci Press, 1983.

[5] M Lillesand \& Kiefer, Remote Sensing and Image Interpretation, New York, John Wiley and Sons, 1993.
[6] Rayes, Luthfi, Metode Inventarisasi Sumber Daya Lahan, Yogyakarta, Penerbit Andi, 2007.

[7] Prahasta, Eddy, Konsep-konsep Dasar Sistem Informasi Geografis,Bandung: Informatika, 2001.

[8] Gunawan,Budi, "Pemanfaatan sistem Informasi Geografis untuk potensi sumber daya lahan pertanian di Kabupaten Kudus", Jurnal sains dan teknologi UMK, vol 4 no 22011. 